\title{
Analysis of Constructive Technologies for improving Energy Performance of Buildings
}

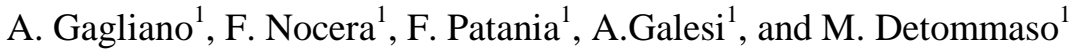 \\ ${ }^{1}$ Department of Industrial Engineering \\ Engineering Faculty, University of Catania \\ Viale A. Doria n.6 - 95125 Catania (Italy) \\ Phone/Fax number:+0039095 7382451, e-mail: agagliano@dii.unict.it, fnocera@ dii.unict.it
}

\begin{abstract}
The current increase in the price of fossil fuel and, consequently, of energy, and the decrease in the availability of these resources, led to the enactment of laws, among which the European Directive 31/2010 on Net Zero Energy Buildings (NZEB), with more strict limits on energy needs. So it is grown the interest in constructive solutions and equipments to reduce heat losses and the energy demand for heating, as well as the study to reduce energy needs for cooling and lighting in order to obtain a zero or nearly energy building.

This study aims to identify solutions for zero energy building design and investigates some construction technologies and equipments in order to optimize the energy performance and to reduce the environmental impact of residential buildings.

A simulation tool was used for the investigation of the feasibility of NZEB applied to a case study.
\end{abstract}

\section{Key words}

Zero Energy Buildings, Energy Saving, Green Roof.

\section{Introduction}

Reduction of energy consumption and the use of energy from renewable sources in the buildings sector constitute important measures needed to reduce energy dependency and greenhouse gas emissions. In the European Union, the Energy Performance of Buildings Directive [1] sets a mandate encouraging member states to take measures to make all new buildings low or net-zero energy by 2020 .

NZEB target, of new or existing building, has become a high priority for architects and multi-disciplinary researchers related to architectural engineering and building physics [2]. The idea of NZEB refers to a building with a net energy consumption of zero over a typical year. It consists in buildings that can satisfy all their energy demands through renewable sources, locally available, non-polluting, low-cost [3]. The target of a ZEB is not only to minimize the energy consumption of the building with passive techniques, but also to design a building that balances energy requirements with active techniques and renewable technologies: i.e, photovoltaic, solar thermal/cooling plants, micro wind turbine [4]. A ZEB is still connected to traditional energy sources (electricity grid, natural gas) so as to be able to use the conventional sources when the Renewable Energy Source (RES) is not in conditions to meet the buildings loads.

If the energy production from RES is greater than of the building energy needs, then the surplus of electricity is transferred to the electricity grid. In current practice, the most common approach to ZEB is to use the electricity grid both as a source and a sink of electricity, thus avoiding the on-site electric storage systems. The term 'net' is used in grid connected buildings to define the energy balance between energy used and energy sold, the term 'net-zero energy' is applied when the balance is zero [5]. This paper describes some possible strategies that can be used to reduce the energy needs of buildings.

Two targeted actions were evaluated: one action on the building envelope and the other on the energy production systems. The first typology of interventions are based on the use of constructive technologies, and of building materials with high insulation properties with the objective to decrease both of the energy demand for heating and cooling [6]. The second typology is based on the use of energy production systems with high efficiency as heat pumps and condensing boilers and others renewable energy sources.

Subsequently the effectiveness of single technological solution was evaluated in order to asses which of them is the most convenient.

\section{The case study}

The case study is a complex of multi floor residential buildings site in Acireale (Catania). It consists of four floors above ground for a total of 39 apartments .

The building facades have the longer sides facing east and west. The main climatic data of the site are shown in table 1. The geographical location belongs to the climatic zone $\mathrm{C}$ [7]. The internal design temperature is assumed $20^{\circ} \mathrm{C}$ in heating period and $26^{\circ} \mathrm{C}$ in cooling period. Conventionally the heating period $(\mathrm{NH})$ is extended from 15 th November to 31th March, and the cooling period (Nc) is extended from 31 th March to 15th November, in this climate zone. 


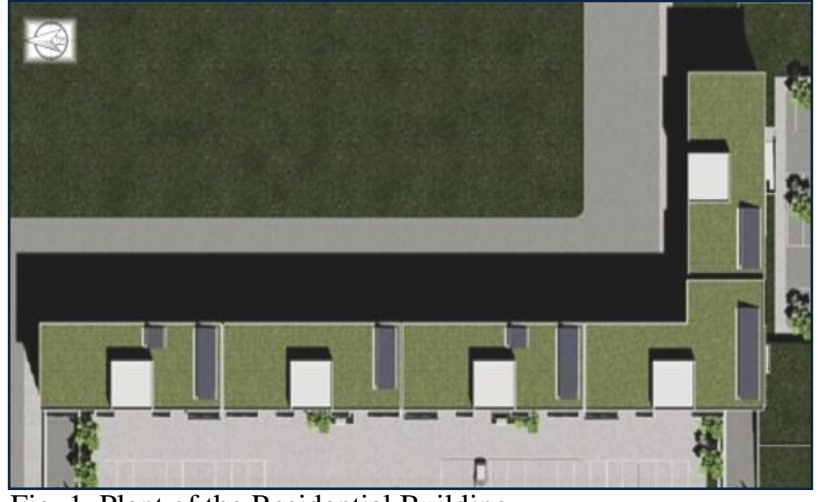

Fig. 1. Plant of the Residential Building

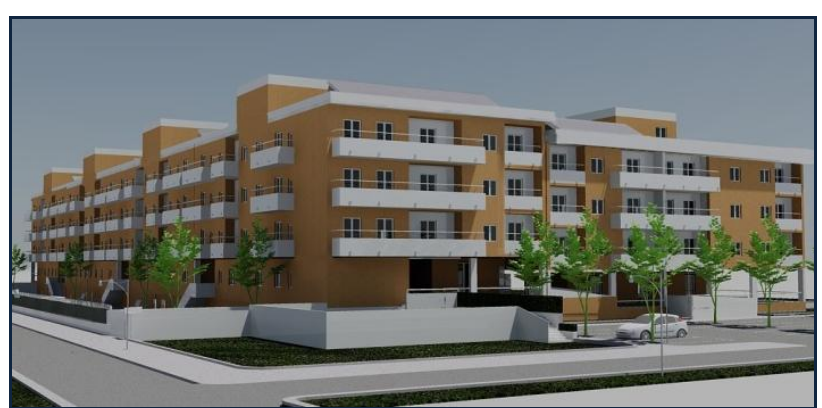

Fig. 2. 3D view of the Residential Building

Table I. - Geomorphologic and climatic data

\begin{tabular}{|l|l|}
\hline District & Acireale \\
\hline Province & Catania \\
\hline Latitude & $37^{\circ} 37^{\prime}$ \\
\hline Climatic zone & C \\
\hline Degree day year & 978 \\
\hline Height above sea level & $200 \mathrm{~m}$ \\
\hline Prevailing wind direction & West \\
\hline Mean wind speed & $4,40 \mathrm{~m} / \mathrm{s}$ \\
\hline
\end{tabular}

The main geometric data of the building are shown in Table II.

Table II. - Geometric data and characteristic parameters

\begin{tabular}{|l|c|l|}
\hline Heated gross-volume & $\mathrm{V}$ & $12580,88 \mathrm{~m}^{3}$ \\
\hline $\begin{array}{l}\text { Surface area of the building envelope that } \\
\text { enclose the heated gross-volume }\end{array}$ & $\mathrm{S}$ & $5250 \mathrm{~m}^{2}$ \\
\hline surface/volume coefficient & $\mathrm{S} / \mathrm{V}$ & $0,417 \mathrm{~m}^{-1}$ \\
\hline Total opaque surface & $\mathrm{S}_{0}$ & $4583 \mathrm{~m}^{2}$ \\
\hline Total transparent surface & $\mathrm{S}_{\mathrm{v}}$ & $667 \mathrm{~m}^{2}$ \\
\hline Net floor area & $\mathrm{S}_{\mathrm{u}}$ & $3189 \mathrm{~m}^{2}$ \\
\hline Ventilation rate & - & $0,30[\mathrm{vol} / \mathrm{h}]$ \\
\hline
\end{tabular}

The building energy performance, based on annual energy use $\left(\mathrm{kWh} / \mathrm{m}^{2} /\right.$ year$)$, was calculated using the software MasterClima Aermec which is based on UNI/TS 11300 norm [8].

\section{A. Energy needs of the "reference" building.}

Preliminarily, We calculated the energy needs considering building envelope which complies with Italian regulations for new constructions (standard envelope), but does not match the target of the NZEB. In table III are reported the thermal characteristics of the building envelope. The building is realized in reinforced concrete (RC) structure with envelope in double brick walls. The roof is a flat roof. The windows are double-glazing made up of two glass panes separated by a layer of air. The thermal energy for heating space and Domestic Hot Water (DHW) production are provided by a thermic fluid heater utilizing natural gas, with an efficiency of about $90 \%$.

Table III. - Opaque envelope and glazing thermal features

\begin{tabular}{|l|l|}
\hline Type & $\mathrm{U}$-value $\left(\mathrm{W} / \mathrm{m}^{2} \mathrm{~K}\right)$ \\
\hline External wall & 0,43 \\
\hline Roof slab & 0,41 \\
\hline Ground Floor & 0,43 \\
\hline Glazing Surfaces & 3,16 \\
\hline Thermal bridge & $0.80 \mathrm{~W} / \mathrm{mK}$ \\
\hline
\end{tabular}

The energy performance calculation was carried out for this "reference" building and the following results were obtained:

- the annual thermal energy demand for winter heating, $\mathrm{Q}_{\mathrm{H}}=155.559 \mathrm{kWh}$,

- the specific annual thermal energy $\mathrm{PE}_{\mathrm{H}, \text { inv }}=48,79$ $\mathrm{kWh} / \mathrm{m}^{2} \mathrm{y}$

- the annual thermal energy demand for DHW production, $\mathrm{Q}_{\mathrm{W}}=55.189 \mathrm{kWh}$,

- the annual energy demand for cooling $Q_{C}=89.861$ $\mathrm{kWh}$

The energy performance certification of buildings requires the calculus of the specific primary energy.

The specific primary energy for winter heating $\mathrm{PE}_{\mathrm{gl}}$ defined as $\mathrm{PE}_{\mathrm{gl}}=\mathrm{PE}_{\mathrm{H}}+\mathrm{PE}_{\mathrm{W}}=\mathrm{Q}_{\mathrm{H}} / \eta_{\mathrm{H}} \mathrm{S}_{\mathrm{u}}+\mathrm{Q}_{\mathrm{W}} / \eta_{\mathrm{W}} \mathrm{S}_{\mathrm{u}}=$ $100,42 \mathrm{kWh} / \mathrm{m}^{2} \mathrm{y}$

The specific primary energy for cooling, defined as :

$\mathrm{PE}_{\mathrm{C}}=\mathrm{Q}_{\mathrm{P}, \mathrm{C}} / \mathrm{S}_{\mathrm{u}}=28,17 \mathrm{kWh} / \mathrm{m}^{2} \mathrm{y}$

With reference to the Italian rule on the energy performance certification of building, the building is rated in $\mathrm{G}$ class, for heating needs, and in class III for the cooling needs.

\section{Techniques to improve the energy performance of building envelope}

Subsequently, We calculated the energy needs of the building after introducing constructive techniques that can improve the building energy performance, that were: "low-E and reflective" windows, ventilated façades, green roof and external wall insulation systems. As regards balcony slabs and roof up stands, thermal bridges are avoided by using special thermally efficient load-bearing connectors [9]. These connectors consist of a pressurebearing module made of micro-fibre high performance concrete, connected with stainless steel bars and insulated with polystyrene hard foam; this system can form a thermal break whilst transferring load and maintaining full integrity with the reinforced concrete structure of the building. 


\section{A. Low-E and reflective windows}

The insulated windows have to limit the heat contributions in summer and realize a good thermal insulation during the heating period.

$$
\begin{aligned}
& U_{g}=1,30\left[\mathrm{~W} / \mathrm{m}^{2} \mathrm{~K}\right] \\
& U_{f}=2,89\left[\mathrm{~W} / \mathrm{m}^{2} \mathrm{~K}\right] \\
& U_{W}=2,00\left[\mathrm{~W} / \mathrm{m}^{2} \mathrm{~K}\right] \\
& g_{g, \ln }=42 \% \\
& \varepsilon=0,1 \\
& \rho=0,9 \\
& s=6-16-6[\mathrm{~mm}]
\end{aligned}
$$

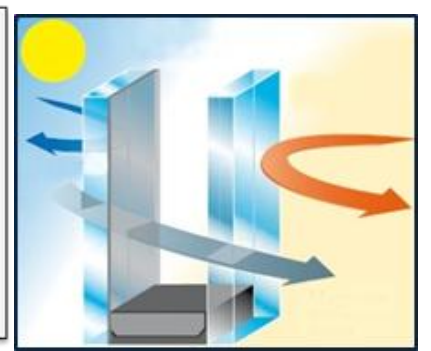

Fig. 3: low-E and reflective windows

Those objectives can be obtained with :

- a low-E coating applied to the glass that reflect long wave radiation and improves the insulation

- reflective coating that reduces the input of solar radiation $(g=42 \%$ ) in the range of near infrared without compromising the light transmission $(77 \%)$.

\section{B. Ventilated facades}

Ventilated facades permit to reduce the energy needs for cooling thanks to the effect of shading of the outer coating, which constitutes a total shield to the incident solar radiation, and the heat transfer within the air channel due to natural convection. This last physical process caused by the effect of air buoyancy within the ventilated channel [10].

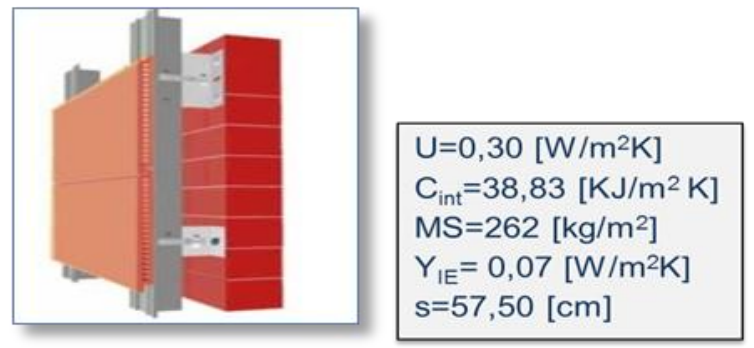

Fig. 4: Ventilated facades

\section{Green roof}

The characteristic layers of the extensive green roof is shown in Figure n.5:

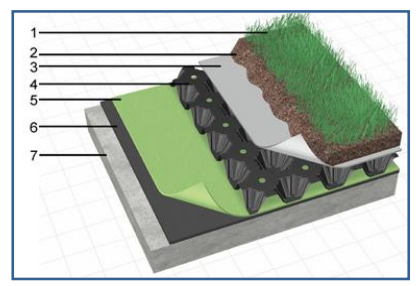

The layer of vegetation; The layer of soil (growing medium); The filter cloth; The dranage layer ; The root-resistant membranes; The waterproof membranes; The insulating layer

Fig 5. Green roof

The green roof energy balance takes in account both the vegetation layer and the soil layer. The adopted energy balance model accounts for [11]:
- long-wave and short-wave radiative exchanges within the plant canopy,

- plant canopy effects on convective heat transfer,

- evapotranspiration from the soil and plants, heat conduction (and storage) in the soil layer,

- moisture dependent thermal properties.

\section{External and load-bearing thermal insulation elements}

A thickness of thermal insulation of $5 \mathrm{~cm}$ placed on the external side of the building envelope reduces the thermal heat losses both from opaque façades and structural thermal bridge.

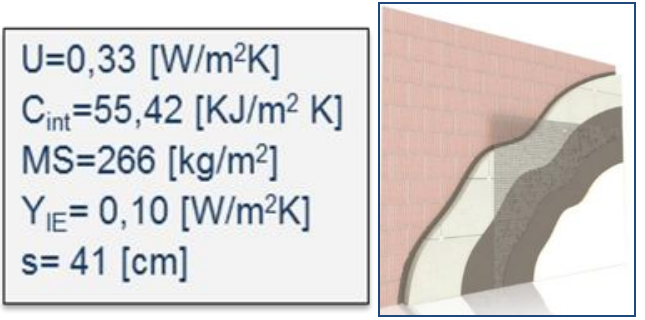

Fig. 5 : External thermal insulation system.

The thermal bridges of the balconies and the roofs can be reduced using special thermal insulating elements able to produce the thermal decoupling. Some technological solutions are achievable, for example using Schöck Isokorb systems.

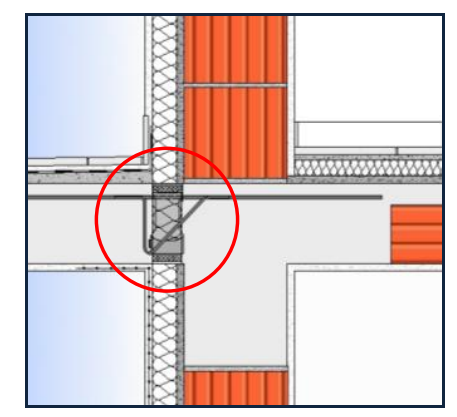

Fig. 6. Fitting floor- isolated cantilever with Schöck Isokorb

In table IV are summarized the main thermal features of the technological solutions analyzed.

Table IV. - Opaque envelope and glazing thermal features

\begin{tabular}{|l|l|}
\hline Type & $\begin{array}{l}\mathrm{U}-\mathrm{value} \\
\left(\mathrm{W} / \mathrm{m}^{2} \mathrm{~K}\right)\end{array}$ \\
\hline Low-E and reflective Windows & 2,00 \\
\hline Green Roof & 0,20 \\
\hline Ventilated Facades & 0,30 \\
\hline External Wall Insulation Systems & 0.33 \\
\hline Thermal bridge ( ) & $0.15 \mathrm{~W} / \mathrm{mK}$ \\
\hline
\end{tabular}

\section{Energy Performance of "NZEB" building envelope}


The energy performance calculation was carried out for the more energy efficient building. The following results were obtained:

- the annual energy demand for winter heating $\mathrm{Q}_{\mathrm{H}}=$ $47.313 \mathrm{kWh}$

- the annual energy demand for DHW production $\mathrm{Q}_{\mathrm{W}}$ did not have any variations ( $55.189 \mathrm{kWh}$ ),

- the annual energy demand for cooling $\mathrm{Q}_{\mathrm{C}}=58.795$ $\mathrm{kWh}$

The specific primary energy for winter heating $\left(\mathrm{PE}_{\mathrm{gl}}\right.$ $\left.=\mathrm{PE}_{\mathrm{H}}+\mathrm{PE}_{\mathrm{W}}=56,95 \mathrm{kWh} / \mathrm{m}^{2} \mathrm{y}\right)$ and consequently the energy performance certification of building was evaluated. The specific primary energy for cooling was $\mathrm{PE}_{\mathrm{C}}=18,43 \mathrm{kWh} / \mathrm{m}^{2} \mathrm{y}$. The following graph shows the comparison between the energy needs of the "reference" building and the building after the energetic retrofit.

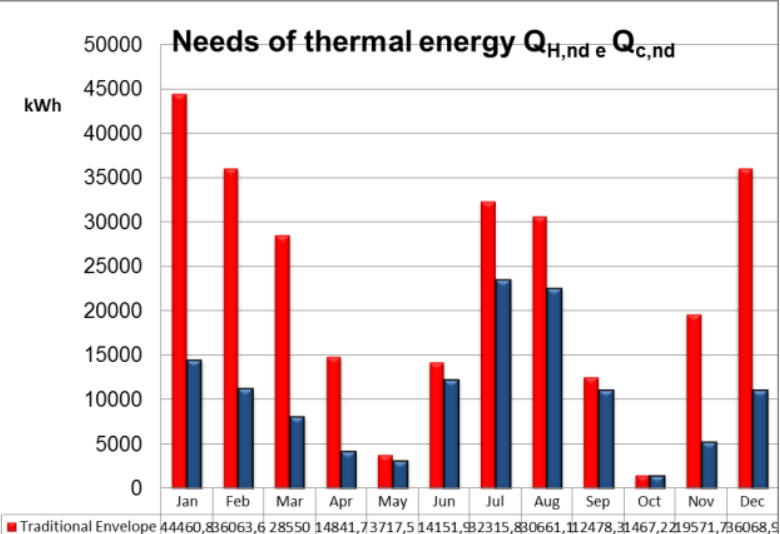

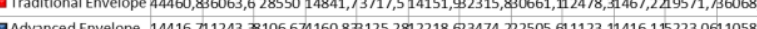

Fig. 7. Energy needs of traditional and advanced building.

The proposed interventions significantly reduce the energy demand during heating period, of about $69 \%$ $(107.876,9 \mathrm{kWh})$, and of about $34 \%(30.886 \mathrm{kWh})$ during the cooling period.

The specific energy for winter heating $P E_{H}, I N V=Q_{H} / S_{u}$ is reduced to $14.83 \mathrm{kWh} / \mathrm{m}^{2} \mathrm{y}$.

Anyway, the request of energy is still high, especially to satisfy the DHW consumptions.

The reduction of energy demand for cooling is mainly due to decrease of the solar gains $\left(\mathrm{Q}_{\text {sol }}\right)$, as showed in figure 8 . The histogram highlights the maximum solar gain reduction in July (41.349 MJ) and the minimum solar gain reduction in December (18.610 MJ).

It is necessary underline that the algorithms of calculus consider stationary conditions, and the thermal losses are calculated with reference to mean weather data (temperature and solar radiation). Obviously this approach doesn't take in account the variations of cooling loads during the day that are closely correlated to the dynamic behaviour of building envelopes. With reference to the Italian rule on the energy performance certification, the building is rated in class $\mathrm{E}$, for the heating needs, and in class II for the cooling needs. To further increase the energetic classification of the building it will be necessary to foresee both the use of a solar thermal plant and improve the efficiency of the thermal energy production system

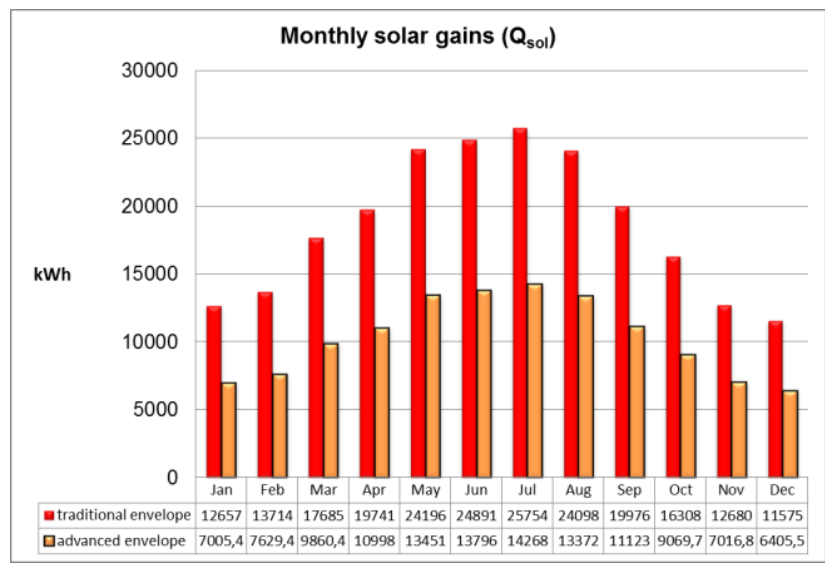

Fig. 8. Solar gains comparison

\section{Analysis of effectiveness of each technology.}

\section{A. Low-e and reflective Windows}

The energy saving globally achieved during all the year is 35.898,60 kWh. The "efficient" windows with lowemissivity coating and solar control allow getting excellent performances in the cooling period. Their application allows to reduce the energy needs required during the cooling period $\left(\mathrm{Q}_{\mathrm{C}}\right)$ of $28.350 \mathrm{kWh}$, and the specific primary energy for cooling $\mathrm{PE}_{\mathrm{C}}$ from 28,17 to $19,23 \mathrm{kWh} / \mathrm{m}^{2} \mathrm{y}$. During heating period the insulated windows do not provide significant reductions in thermal energy demand, $(4.275 \mathrm{kWh})$ due to the reduction of solar gain. The specific primary energy for heating $\left(\mathrm{PE}_{\mathrm{H}}\right)$ is reduced from 62,66 to $61,03 \mathrm{kWh} / \mathrm{m}^{2} \mathrm{y}$

\section{B. Ventilated façades}

The energy saving globally achieved during all the year is $14.325,30 \mathrm{kWh}$, of which $10.097 \mathrm{kWh}$ are achieved during the cooling period. The greatest reduction of energy needs is achieved in the months of July and August respectively with an energy saving of $3.000 \mathrm{kWh}$ and $2.942 \mathrm{kWh}$. The replacement of traditional masonry with ventilated facades reduce the specific primary energy for cooling $\mathrm{PE}_{\mathrm{C}}$ from 28,17 to $25,10 \mathrm{kWh} / \mathrm{m}^{2} \mathrm{y}$ and for heating $\mathrm{PE}_{\mathrm{H}}$ from 62,66 to $59,83 \mathrm{kWh} / \mathrm{m}^{2} \mathrm{y}$.

\section{Green Roof}

The green roof contributes to reduce the energy demand in all the months of the year. It reduces the specific primary energy for winter heating $\mathrm{PE}_{\mathrm{H}}$ from 62,66 to 61,54 $\mathrm{kWh} / \mathrm{m}^{2} \mathrm{y}$, and the specific primary energy for cooling $\mathrm{PE}_{\mathrm{C}}$ from 28,17 to $26,44 \mathrm{kWh} / \mathrm{m}^{2} \mathrm{y}$. The contribute of green roof on the thermal performance of the building could seem modest, but it is due to the fact that only the apartments of upper floor are directly affected by its beneficial effects. In the following figure 9 the thermal energy exchanged through the green roof is compared with the energy exchanged through the traditional roof, considering a reference surface of $1000 \mathrm{~m}^{2}$ 


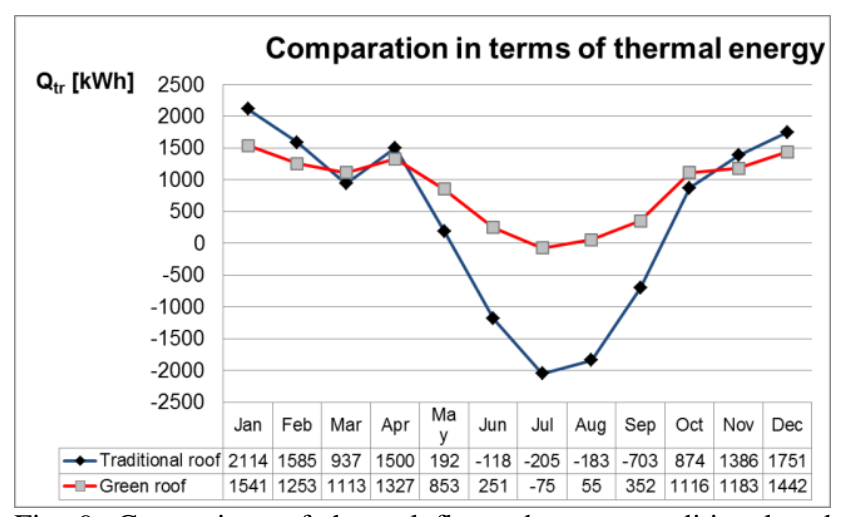

Fig. 9. Comparison of thermal fluxes between traditional and green roof

The graph highlights that the green roof has a greater positive energy balance than traditional roof during all the year. The only exception is during the month of March, with an incoming energy flux more higher respect to the traditional roof of $176 \mathrm{kWh}$. The most significant savings of energy demand for cooling are obtained during the most critical summer months. In July it can be noted a reduction of cooling needs of $1701 \mathrm{kWh}$.

\section{External and load-bearing thermal insulation elements}

The annual energy saving achieved with external and load-bearing thermal insulation elements amounts to $80.976,7 \mathrm{kWh}$. In the case study the correction of thermal bridges has allowed to significantly reduce the specific primary energy for winter heating, $\mathrm{PE}_{\mathrm{H}}$, from 62,66 to $22,91 \mathrm{kWh} / \mathrm{m}^{2} \mathrm{y}$. The correction of the thermal bridges with external wall insulation systems makes the building very isolated and reduces the heat losses during the heating period but also may lead to increase the needs for cooling especially during the springer/autumn months.

In this context, it can be noted an increase in the energy demand in the months of May, June and September: the specific primary energy for cooling $\mathrm{PE}_{\mathrm{C}}$ increases from 28,17 to $38,87 \mathrm{kWh} / \mathrm{m}^{2} \mathrm{y}$.

\section{E. The Normalized Energy saving NEs}

To assess the effectiveness of the energy saving obtainable by each building technology, the Normalised Energy saving $\mathrm{NEs}_{\mathrm{ij}}$ it has defined as follow:

$$
\mathrm{NEs}_{\mathrm{ij}}=\mathrm{Es}_{\mathrm{ij}} / \Sigma \mathrm{S}_{\mathrm{j}}
$$

Where

$\mathrm{Es}_{\mathrm{ij}}=$ energy saving obtainable by the technology $\mathrm{j}$ for the i-mi month

$\Sigma \mathrm{S}_{\mathrm{j}}=$ surface where is applied the technology $\mathrm{j}$

Figure 10 shows the monthly energy saving normalized respect to the surface. It can be noted that:

- insulated windows are much more energy efficient than the other analysed components, both in the summer and winter months

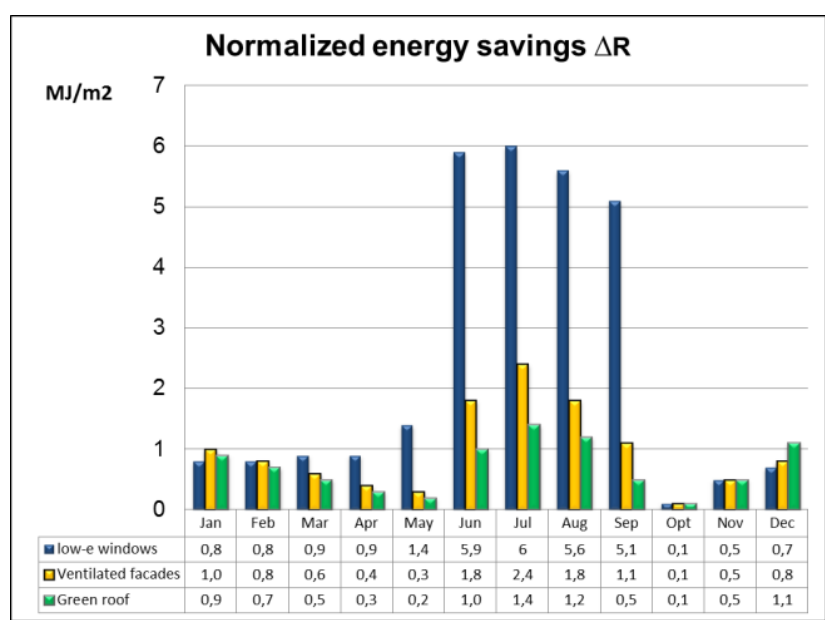

Fig. 10. Normalized energy saving of building components

- ventilated facades give an useful contribution all year around, and are much energy efficient during the summer months ( June, July, August and September). green roof gives the lowest values in all the months. This result depends, as previously reported, by the fact that only the apartments of upper floor can directly take advantages by its effects.

\section{Solar thermal plant}

The amount of thermal energy request for DHW constitutes a significant aliquot of the total energy demand of the building. Indeed, the primary energy for domestic hot water $\mathrm{PE}_{\mathrm{W}}$ amounted to $37.75 \mathrm{kWh} / \mathrm{m}^{2} \mathrm{y}$ that is more than half of the value of the global primary energy $\mathrm{PE}_{\mathrm{gl}}=$ $56,56 \mathrm{kWh} / \mathrm{m}^{2} \mathrm{y}$ in the case of optimized building envelope.

So, to reduce the primary energy requirement becomes, therefore, indispensable the use of renewable energy sources. For this purpose it was provided the installation of solar flat plate panels on the roof of the building.

To this aim it was calculated the amount of solar collector to completely satisfy the energy demand for DHW using the data of solar radiation available and the "f chart" method. The results give a need of $3 \mathrm{~m}^{2}$ of solar panel (south oriented and $35^{\circ}$ of tilt angle) for each apartment, so globally it should be necessary an area of about $120 \mathrm{~m}^{2}$. Each apartment is also equipped with a highly effective stratified storage tank of 250 litres to accumulate hot water. Introducing the solar thermal plant, the specific primary energy for domestic hot water $\mathrm{PE}_{\mathrm{W}}$ is reduced from $37,75 \mathrm{kWh} / \mathrm{m}^{2} \mathrm{y}$ to zero, and the global specific primary energy $P E_{\mathrm{gl}}$ is reduced to $19,16 \mathrm{kWh} / \mathrm{m}^{2} \mathrm{y}$.

This building configuration permits to reach the $\mathrm{B}$ class in accordance with the energy classification.

\section{Energy production systems: condensing boiler and heat pumps}

The energy performance of building is further optimized through the use of a thermal generation systems with high efficiency. Two different solutions were considered:

- Condensing boiler

- Heat pump 


\section{A. Condensing boiler}

A condensing boiler is a high efficiency modern boiler that incorporates an extra heat exchanger so that the hot exhaust gases lose much of their energy to pre-heat the water in the boiler system. When working at peak efficiency, the water vapour produced in the combustion process condenses back into liquid form releasing the latent heat of vaporization. As well know the performance, couched in terms of operating thermal efficiency, of a condensing boiler is a function both of boiler design as well as boiler operation, the latter a function of the hydronic system design and controls.

It is reasonable consider an average seasonal efficiency $\left(\eta_{\mathrm{gms}}\right)$ equal to $98 \%$. In this hypothesis the specific primary energy for the winter heating $\mathrm{PE}_{\mathrm{gl}}$ is reduced from 19,16 to $15,13 \mathrm{kWh} / \mathrm{m}^{2} \mathrm{y}$.

\section{B. Heat pump}

The replacement of standard boilers with heat pumps constitutes an interesting opportunity for the reduction of the specific primary energy performance.

The coefficient of performance COP of a heat pump is closely related to the temperature lift, i.e. the difference between the temperature of the heat source and the output temperature of the heat pump, (condensation - evaporation temperature). The operating performance of an electric heat pump over the season is called the seasonal performance factor (SPF). It is defined as the ratio of the heat delivered and the total energy supplied over the season. It takes into account the variable heating and/or cooling demands, the variable heat source and sink temperatures over the year, and includes the energy demand, for example, for defrosting. The SPF can be used for comparing heat pumps with conventional heating systems (e.g. boilers), with regards to primary energy saving.So, considering an Air Source Heat Pumps with a $\mathrm{SPF}=1,40$, the specific primary energy $\mathrm{PE}_{\mathrm{gl}}$ is reduced from 19,16 to $10,60 \mathrm{kWh} / \mathrm{m}^{2} \mathrm{y}$.In this way the building reaches the energy class $\mathrm{A}$.

The use of heat pumps resets the fuel needs but involves a considerable demand of electric energy equal to 9655,17 $\mathrm{kWh}$ which should be covered from other renewable energy sources [12] (i.e. PV plant or Small Wind Turbine).

\section{Zero Energy Building}

The target of a ZEB is not only to minimize the energy consumption of the building with passive techniques, but also to design a building that balances energy requirements with active techniques and renewable technologies. So, it must be also considered the reduction of the energy requirements for lighting and other use. In this optics it is necessary to foresee other energy renewable source integrated in the building.

It is simple to calculate the amount of photovoltaic solar collector to balance the electricity demand of building. This electricity need can be evaluated as about $4.000 \mathrm{kWh}$ per year per apartment, so $160.000 \mathrm{kWh}$ have to be provided. Using the PvGis tools it has calculated the electrical energy production for $1 \mathrm{kWp}$ of PV plant south oriented with a tilt angle of $40^{\circ}$, which give $1470 \mathrm{kWh} / \mathrm{y}$. Consequently, it should be required a plant with a potentiality of about $110 \mathrm{kWp}$, and $900 \mathrm{~m}^{2}$ of surface to install the solar panels. The considerable amount of area required for the installation of photovoltaic and solar thermal panels, including their fitting, requires an accurate study in the design phase [13]

\section{Conclusions}

The study analyse some technological strategies, and on to achieve the target of ZEB or NZEB, acting both on the building envelope and on the thermal generation system.

For each typologies of intervention (ventilated facades, green roofs, insulated glasses and external wall insulation) the obtainable energy saving has been evaluated. All the proposed solutions provide a significant contribution to the reduction of energy demand of the building, but they are not sufficient to completely satisfy the energy needs of the building. To aim this objective it is necessary to foresee the use of renewable energy sources.

To obtain a ZEB it is necessary to install a photovoltaic plant of $110 \mathrm{kWp}$ and $120 \mathrm{~m}^{2}$ of solar thermal panels.

The cost analysis of the solutions proposed has indicates an extra cost $165.463,56 €$, considering the FIT (tax deductions) that will be really with a payback period of 13 - 14 years.

\section{References}

[1] Directive 2010/31/EU of the European Parliament and of the Council of 19 May 2010 on the energy performance of buildings.

[2] P. Torricelli, S. Pless., M. Deru, Zero Energy Buildings: A critical look at the definition, U.S. department of energy, 2006, pag. 1 .

[3] L. Wang, J. Gwilliam, P. Jones, Case study of zero energy house design in UK, Energy and Buildings 41 (2009) 12151222

[4] F. Patania, A. Gagliano, F. Nocera, A. Galesi. Development of the solar cooling in mediterranean area, PLEA 2011, vol. 1, pp.639-647

[5] P. Hernandez, P. Kenny, From net energy to zero energy buildings: Defining life cycle zero energy buildings (LCZEB),Energy and Buildings 42 (2010) 815-821

[6] F. Sicurella, G. Evola, E. Wurtz, A statistical approach for the evaluation of thermal and visual comfort in free-running buildings. Energy and Buildings, 47, 2012, 402-410

[7] Legislative Decree 192/2005

[8] Master Clima Aermec 11300 1.32 LE, 2010, Guida di MC Impianti 11300

[9] G. Evola, G.Margani, L. Marletta, Energy and cost evaluation of thermal bridge correction in Mediterranean climate. Energy and Buildings, 43, 2011, 2385-2393

[10] F. Patania, A. Gagliano, F. Nocera, F. Ferlito, A. Galesi, Thermo fluid dynamic analyses of ventilated facades, Energy and Buildings 42, 2010, 1148-1155.

[11] Frankestein, Koenig, Model of energy balance of a vegetated rooftop, Army Corps of Engineers' FASST vegetation models, 2008

[12] A. Gagliano , F. Patania, F. Nocera, A. Capizzi, A. Galesi A proposed methodology for estimating the performance of small wind turbines in urban area - SEB 11- 2011

[13] A. Gagliano , F. Patania, F. Nocera, A. Capizzi, A. Galesi, GIS-based decision support for solar photovoltaic planning in urban environment. SEB 12- 2012 